\title{
BENZENE, TOLUENE AND XYLENE BIODEGRADATION BY PSEUDOMONAS PUTIDA CCMI 852
}

\section{Marcelo Henrique Otenio ${ }^{1}$; Maria Teresa Lopes da Silva²; Maria Luiza Oliveira Marques²; José Carlos Roseiro²; Ederio Dino Bidoia ${ }^{1 *}$}

${ }^{1}$ Instituto de Biociências, Departamento de Bioquímica e Microbiologia, Universidade Estadual Paulista, Rio Claro, SP, Brasil. ${ }^{2}$ Laboratório de Microbiologia Industrial, Instituto Nacional de Engenharia e Tecnologia Industrial, Estrada do Paço do Lumiar, Lisboa, Portugal.

Submitted: May 11, 2004; Returned to authors for corrections: April 25, 2005; Approved: September 20, 2005

\begin{abstract}
A minimal liquid medium containing benzene $(\mathrm{B})$, toluene $(\mathrm{T})$ and xylene $(\mathrm{X})$ and mixtures thereof, was used to evaluate degradation activity of Pseudomonas putida CCMI 852 containing a TOL plasmid. Experiments were developed with B, T and X $\left(100 \mathrm{mg} \mathrm{L}^{-1}\right)$, with mixtures of BT, BX, and TX $\left(50+50 \mathrm{mg} \mathrm{L}^{-1}\right.$ each $)$ and BTX $\left(33.3+33.3+33.3 \mathrm{mg} \mathrm{L}^{-1}\right.$ each), added to $500 \mathrm{~mL}$ of medium. After 18 to 24 hours, the inoculum was added and solvent disappearance was determined after 24 to 25 hours by GC. Results showed that $P$. putida CCMI 852 was able to metabolize T and X, but B was not metabolized. In a BTX mixture, B was not metabolized and T and $\mathrm{X}$ degradation rate decreased $50 \%$.
\end{abstract}

Key words: Pseudomonas putida, biodegradation, BTX, plasmid TOL

\section{INTRODUCTION}

Benzene, toluene and xylene isomers (BTX) are the major components of gasoline (5). Because of their low water solubility and their acute toxicity and genotoxicity (6), BTX components are classified as priority pollutants by the U.S. Environmental Protection Agency (9). Due to the sequences of accidental gasoline spills and leakage from service station tanks, they are prime sources of aquifer contamination (3).

BTX degradation by microorganisms possesses several advantages over traditional methods $(2,4,13,14)$. Enriched cultures obtained from soil exposed to BTX mineralized benzene and Toluene and co-metabolized Xylene isomers, producing polymeric residues (17).

The screening of 297 bacterial isolates from soil revealed their ability to degrade hydrocarbons constituent of gasoline, and $75 \%$ of the isolates grew on toluene vapor as sole carbon and energy source (16). Benzene and naphthalene were less frequently degraded than substituted aromatics. These nonsubstituted hydrocarbons were degraded by a microbial consortium growing on gasoline, suggesting co-oxidative or syntrophism processes (16).

When bacterial cells were exposed to mixtures of aromatics present at equal concentrations, degradation patterns were modified substantially from those of individual BTEX compounds, disappearing according to the sequence ethylbenzene, toluene, benzene and xylene (7).

Bacteria able to degrade toluene and xylene are also able to degrade benzene. When the two compounds were present together, they exerted an antagonist effect, i.e. they were degraded at a lower rate than toluene and xylene alone (1).

Pseudomonas can adapt to diverse substrates and possess several catabolic pathways capable of acting on recalcitrant substances. Some studies with Pseudomonas putida identified metabolic pathways dedicated to gasoline components, like benzene, toluene and xylene. Also, they show a schematic diagram of the metabolic pathways constructed in P. putida for degradation of the BTX mixture $(12,15)$. The TOL pathway in BTX mixture biodegradation does not utilize benzene as a substrate (12). P. putida PaW15 initiates toluene degradation at

*Corresponding Author. Mailing address: Instituto de Biociências, Departamento de Bioquímica e Microbiologia - UNESP. 13506-900, Rio Claro, SP, Brasil. Tel.: (+5519) 3526-4191, Fax: (+5519) 3526-4176. E-mail: ederio@rc.unesp.br 
the methyl group, eventually forming benzoate, which is degraded by the meta cleavage route. Xylene also undergoes the same oxidative reaction, giving rise to the methyl-benzylalcohol formation. However, TOD pathway utilizes benzene as substrate (15).

The aim of the present work was to characterize and quantify the activity of Pseudomonas putida CCMI 852, on benzene, toluene, xylene and mixtures thereof.

\section{MATERIALS AND METHODS}

\section{Microorganism and inoculum preparation}

Pseudomonas putida CCMI 852 from the Culture Collection of Industrial Microorganisms was isolated from an effluent treatment plant (Frielas, Portugal). The strain was identified using the Biolog system for microbial identification (Biolog Inc., USA) and maintained as freeze-dried cultures. Slants of TSA were obtained by growth at $30^{\circ} \mathrm{C}$ for twenty-four hours. Cells were removed from the slants and transferred into $1000 \mathrm{~mL}$ screw capped cultivation flasks containing $500 \mathrm{~mL}$ of mineral medium of the following composition (per liter): $\mathrm{KH}_{2} \mathrm{PO}_{4} 1.36 \mathrm{~g} ; \mathrm{Na}_{2} \mathrm{HPO}_{4}$ $1.42 \mathrm{~g}$; $\left(\mathrm{NH}_{4}\right)_{2} \mathrm{SO}_{4} 2.38 \mathrm{~g}$; and $2 \mathrm{~mL}$ of a micro-nutrient elements solution (18). Benzene, toluene and xylene were used as carbon sources.

\section{Biodegradation Tests}

A bottom side-arm with a silicon membrane and aluminum cap was used to remove samples from the flasks, using a sterile syringe and needle. Benzene (P.A. Merck, Germany), toluene (P.A. Merck, Germany) and xylene (mixtures of isomers, P.A. Merck, Germany), were added to $500 \mathrm{~mL}$ of minimal medium (100 $\mathrm{mg} \mathrm{L}^{-1}$ in single substrate media, $50 \mathrm{mg} \mathrm{L}^{-1}$ of each solvent in two component mixtures, and $33.3 \mathrm{mg} \mathrm{L}^{-1}$ of each solvent in the three component mixture) and incubated at $30^{\circ} \mathrm{C}$, in an orbital shaker at $130 \mathrm{rpm}$, allowing the complete equilibrium BTX partition between the vapor phase and liquid phase for 24 hours, before inoculation (14).

After inoculation, samples were taken at time intervals and analyzed after the depletion of B, T, X, BT, BX, TX and BTX. Parallel experiments were carried out using a control flask, where the solvents B,T and $\mathrm{X}$, and mixtures thereof in the mineral medium were analyzed to assess abiotic losses (2,7). All experiments were performed in duplicate, and abiotic losses were subtracted by sampling an identical but uninoculated bottle.

\section{Methods}

DNA was extracted according to the described methods $(8,11,19)$. Samples were removed from the cultures and solvent content was determined by gas-liquid chromatography in a Varian 3800 gas-liquid chromatograph (USA), equipped with a flame ionization detector. Separation was carried out on a $10 \mathrm{~m} \times 0.20 \mathrm{~mm}$ fused silica capillary column (film $1.2 \mu \mathrm{m}$ ), SPB-1
(Supelco, USA) using Helium as carrier, at a flow rate of $10 \mathrm{~mL}$ $\min ^{-1}$. The column temperature was programmed at an initial temperature of $40^{\circ} \mathrm{C}$ for $1 \mathrm{~min}$, then increased at $20^{\circ} \mathrm{C} \mathrm{min} \mathrm{m}^{-1}$ to $160^{\circ} \mathrm{C}$ and held there for $8 \mathrm{~min}$. Injector and detector temperatures were $250^{\circ} \mathrm{C}$ and $260^{\circ} \mathrm{C}$, respectively. Splitless injection was used. For the extraction of the solvents, SPME fiber ${ }^{\mathrm{TM}}$ coated with a $100 \mathrm{~mm}$ coated Polydimethylsiloxane layer was used immersed in the sample. The exposure time was 5 minutes with vigorous stirring at room temperature. The SPME fiber ${ }^{\mathrm{TM}}$ was then injected into the chromatograph (9). Each sample was injected twice.

\section{RESULTS}

Different degradation rates were found in shake flasks containing B, T, and X. Toluene was degraded at a two-fold rate than xylene. Benzene concentration remained unchanged. When degrading two component mixtures, toluene was utilized at a rate by $73 \%$ lower in the presence of benzene and at a rate by $37 \%$ lower in the presence of xylene. The utilization of xylene also decreased by $53 \%$ in the presence of benzene and by $15 \%$ in the presence of toluene. Benzene concentration remained unchanged. The three components mixture also revealed a decreased specific degradation rate of toluene (57\%) and xylene (49\%). In the presence of individual substrates, the induction time was 19 hours. In the two and three components mixtures, the induction times varied in a non-uniform pattern, ranging between 16.5 and 26 hours (Table 1).

Table 1. Induction time and degradation rates for benzene (B), toluene (T) and xylene (X), and mixtures thereof by P. putida CCMI 852.

\begin{tabular}{|c|c|c|c|}
\hline & & $\begin{array}{l}\text { Induction } \\
\text { time (h) }\end{array}$ & $\begin{array}{l}\text { Volumetric degradation } \\
\text { rate }\left(\mathrm{mg} \text { solvent } \mathrm{L}^{-1} \mathrm{~h}^{-1}\right)\end{array}$ \\
\hline 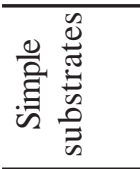 & $\begin{array}{l}\mathbf{B} \\
\mathbf{T} \\
\mathbf{X}\end{array}$ & $\begin{array}{c}0.0 \\
19.0 \\
19.0\end{array}$ & $\begin{array}{l}0.00 \\
5.32 \\
2.55\end{array}$ \\
\hline 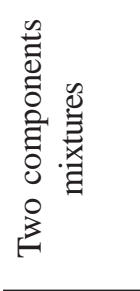 & $\begin{array}{l}\mathbf{B} \\
\mathbf{T} \\
\mathbf{B} \\
\mathbf{X} \\
\mathbf{T} \\
\mathbf{X}\end{array}$ & $\begin{array}{c}0.0 \\
26.0 \\
0.0 \\
16.5 \\
19.0 \\
19.0\end{array}$ & $\begin{array}{l}0.00 \\
1.45 \\
0.00 \\
1.20 \\
3.37 \\
2.18\end{array}$ \\
\hline 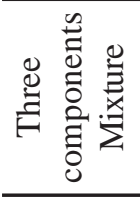 & $\begin{array}{l}\mathbf{B} \\
\mathbf{T} \\
\mathbf{X}\end{array}$ & $\begin{array}{c}0.0 \\
16.5 \\
16.5\end{array}$ & $\begin{array}{l}0.00 \\
2.31 \\
1.29\end{array}$ \\
\hline
\end{tabular}


The electrophoretic profiles of DNA and DNA plasmid digested with restriction enzyme from $P$. putida CCMI 852 showed to be a megaplasmid (Fig. 1A and B). Enzymatic restriction with Hind III showed a plasmid restriction profile with 10 fragments corresponding to TOL standard plasmid profile pWWO.

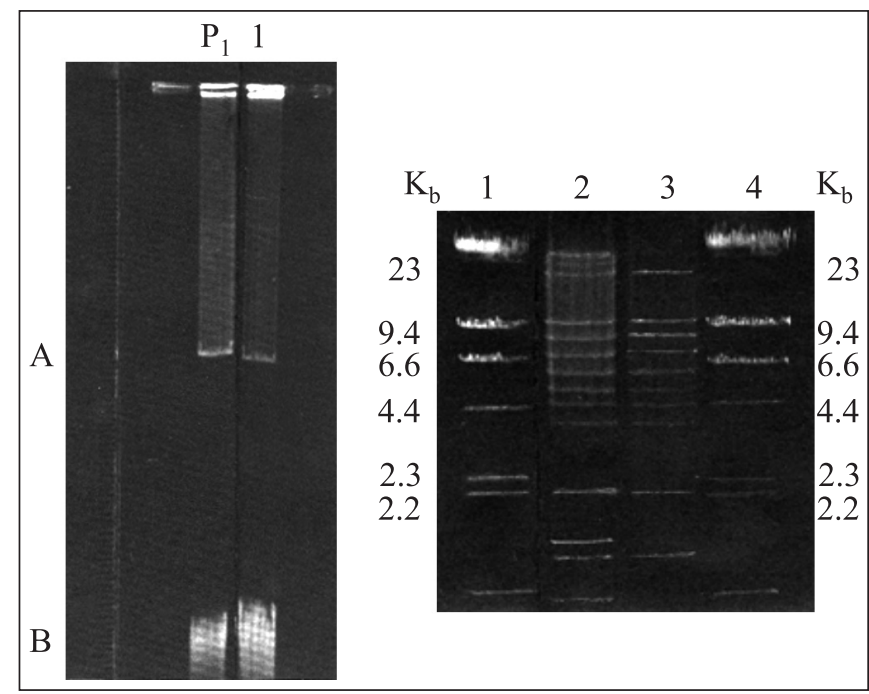

Figure 1. Electrophoretic profile of plasmidial DNA (A) and restriction digestion of the plasmid (B) agarose gel. $\mathrm{P}_{1}$ is $P$. putida $\mathrm{mt}_{2}$ (NCIB 12182, CCMI 747) DNA which is known to contain the TOL plasmid pWWO, and 1 is $P$. putida CCMI 852 DNA.

\section{DISCUSSION}

The degradation of both toluene and xylene were affected by the presence of the third component benzene. When comparing toluene and xylene volumetric degradation rates determined on sole substrates and in substrate mixtures, it was observed that toluene and xylene volumetric degradation rates decreased when the microorganism grew in media with two or three carbon components. The decrease was more pronounced in the presence of benzene (BT, BX and BTX) than in the presence of other components (TX).

P. putida did not degrade benzene, alone or together with toluene or p-xylene and these results are in agreement with Chang et al. (4). However, these authors reported that benzene did not affect the degradation rate of toluene or p-xylene, and here it was demonstrated that the presence of benzene inhibited toluene and xylene degradation, irrespective of whether the microorganism grew in two or three components mixtures.

The degradation of toluene/xylene suggests the presence of the TOL pathway in the microorganism (Fig. 2). Fig. 1A and B shows that $P$. putida CCMI 852 contains a plasmid, and it is

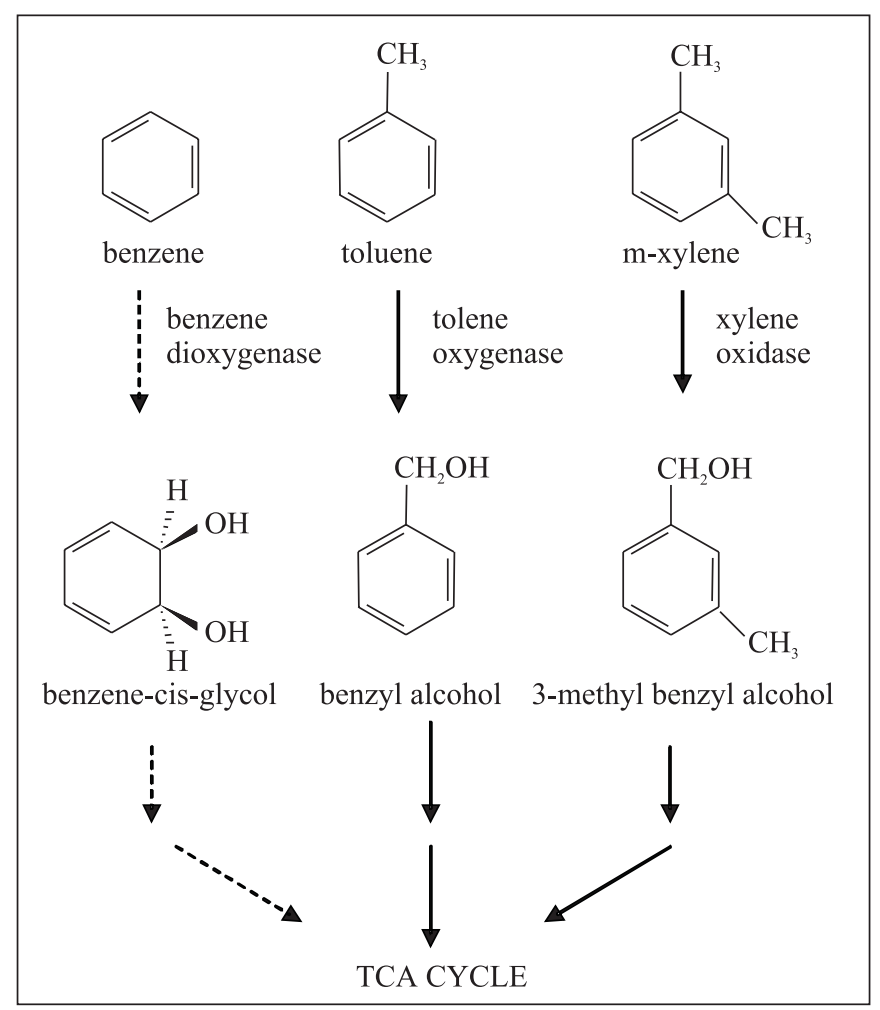

Figure 2. Metabolic pathway suggested, for the degradation of the BTX mixture by $P$. putida. Dotted lines represent the TOD pathway and solid lines, the TOL pathway (Lee et al., 1994).

likely to be a TOL plasmid, as it is referred in literature that BTX biodegradation is usually associated to DNA plasmidic expression (12). It is known that structural genes for the catabolic enzymes are clustered in two operons of the TOL plasmid (10). As mentioned above, TOL pathway in the BTX mixture utilizes toluene and xylene, probably as a detoxification mechanism. This work suggests that $P$. putida CCMI 852 may not encode the TOD pathway and, therefore, benzene degradation could not be expressed.

\section{ACKNOWLEDGMENTS}

Marcelo Otenio wishes to express gratitude to Rotary International Program for financial support.

\section{RESUMO}

\section{Biodegradação de benzeno, tolueno e xileno pela Pseudomonas putida CCMI 852}

Meio mineral líquido contendo benzeno (B) ou tolueno (T) ou xileno (X) a $100 \mathrm{mg} \mathrm{L}^{-1}$ e suas misturas de BT, BX e TX (50 + $50 \mathrm{mg} \mathrm{L}^{-1}$ cada mistura $)$ e BTX $\left(33,3+33,3+33,3 \mathrm{mg} \mathrm{L}^{-1}\right.$ cada 
mistura) foram utilizados para avaliar a atividade de degradação de B, T e X por Pseudomonas putida CCMI 852 contendo um plasmídeo TOL. Após 18 a 24 horas de homogenização da mistura, o inoculo foi adicionado e o decréscimo da concentração dos solventes foi determinado entre 24 e 25 horas por GC. Pseudomonas putida CCMI 852 foi capaz de metabolizar T e X, mas não B. Na mistura BTX, B não foi metabolizado também e a velocidade de degradação de $\mathrm{T}$ e X decresceu cerca de $50 \%$ comparado com soluções contendo apenas T ou X.

Palavras-chave: Pseudomonas putida, biodegradação, BTX, plasmídeo TOL

\section{REFERENCES}

1. Arvin, E.; Jensen, B.K.; Gundersen, A.T. Substrate interactions during aerobic biodegradation of benzene. Appl. Environ. Microbiol., 55, 3221-3225, 1989.

2. Baldwin, B.R.; Nakatsu, C.H.; Nies, L. Detection and Enumeration of Aromatic Oxygenase Genes by Multiplex and Real-Time PCR. Appl. Environ. Microbiol., 69, 3350-3358, 2003.

3. Barbee, G.C.; Brown, K.W. Movement of xylene through in saturated soils following simulated spills. Water Air Soil Pollut., 29, 321-331, 1986.

4. Chang, M.; Voice, T.C.; Criddle C.S. Kinetics of competitive inhibition and cometabolism in the biodegradation of benzene, and p-xylene by two Pseudomonas isolates. Biotech. Bioengin., 41, 1057-1065, 1999.

5. Cunha, C.D.; Leite, S.G.F. Gasoline biodegradation in different soil microscoms. Braz. J. Microbiol., 31, 45-49, 2000.

6. Dean, B.J. Recent findings on the genetic toxicology of benzene, toluene, xylene and phenols. Mutat. Res., 145, 153-181, 1985.

7. Deeb, R.A.; Alvarez-Cohen; L. Temperature effects and substrate interactions during the aerobic biotransformation of BTEX mixtures by toluene-enriched consortia and Rhodococcus rhodochrous. Biotech. Bioengin., 62, 526-536, 1999.
8. Dillon, J.; Nasin, R.A.; Nestmann, E.R. Recombinant DNA methodology. John Wile \& Sons, New York, 1985.

9. Eriksson, M.; Swartling, A.; Dalhammar, G. Biological degradation of diesel fuel in water and soil monitored with solid-phase microextraction and GC-MS. Appl. Microbiol. Biotechnol., 50, 129-124, 1998.

10. Harayama, S. Degradation of environmental pollutants by microorganism and their metalloenzymes. In: Sigel, H.; Sigel, A (eds). Metal ions and biological systems. Marcel Dekker, New York, 1992, p.99-156

11. Kado, C.I.; Liu, S.T. Rapid procedure of detection and isolation of large and small plasmids. J. Bacteriol., 3, 1965-1373, 1981.

12. Lee, J-Y.; Roh, J.R.; Kim, H.S. Metabolic engineering of Pseudomonas putida for the simultaneous biodegradation of benzene, toluene, and p-xylene mixture. Biotech. Bioengin., 43, 1146-1152, 1994.

13. Mesarch, M.B.; Nakatsu, C.H.; Nies, L. Development of Catechol 2,3-Dioxygenase-Specific Primers for Monitoring Bioremediation by Competitive Quantitative PCR. Appl. Environ. Microbiol., 66, 678-683, 2000

14. Oh, Y.S.; Shareefdeen, Z.; Baltzis, B.C.; Bartha, R. Interations between benzene, toluene, and xylene during their biodegradation. Biotech. Bioengin., 44, 533-538, 1994.

15. Parales, R.E.; Ditty, J.L.; Harwood, C.S. Toluene-degrading bacteria are chemotactic towards the environmental pollutants benzene toluene, and trichloroethylene. Appl. Environ. Microbiol., 66, 40984104, 2000

16. Ridgway, H.F.; Safarik J.; Phipps, D.; Carl, P.; Clark, D. Identification and catabolic activity of well-derived gasoline degrading bacteria from a contaminated aquifer. Appl. Environ. Microbiol,. 56, 35653575,1990

17. Tsao, C-W.; Song, H-G.; Bartha R. Metabolism of benzene, toluene, and xylene hydrocarbons in soil. Appl. Environ. Microbiol., 64 4924-4929, 1998.

18. Vishiniac, W.; Santer, M. The Thiobacilli. Bacteriol. Rev., 21, 195213, 1957

19. Wheatcroft, R.; Williams, P.A. Rapid methods for the study of both stable and unstable plasmids in Pseudomonas. J. Gen. Microbiol. 124, 433-437, 1981. 